\title{
Acute onset common peroneal nerve palsy in a child due to fibular head osteochondroma: a case report
}

\author{
Swapnil M. Keny ${ }^{1}$, Lokesh Dabral ${ }^{1}$, Prashant Meshram ${ }^{2 *}$, Naved Ansari ${ }^{3}$, Nikhil Gokhale ${ }^{1}$, \\ Shashikant Nawale ${ }^{1}$, Abhishek Jaroli ${ }^{1}$
}

\author{
${ }^{1}$ Department of Orthopaedics, K B Bhabha Municipal General Hospital, Mumbai, Maharashtra, India \\ ${ }^{2}$ Orthocure Medical Center, Dubai, UAE \\ ${ }^{3}$ Department of Orthopaedics, Grant Government Medical College and Sir J. J. Group of Hospitals, Mumbai, \\ Maharashtra, India
}

Received: 18 December 2021

Revised: 10 February 2022

Accepted: 11 February 2022

\section{*Correspondence:}

Dr. Prashant Meshram,

E-mail: drmeshramortho@gmail.com

Copyright: () the author(s), publisher and licensee Medip Academy. This is an open-access article distributed under the terms of the Creative Commons Attribution Non-Commercial License, which permits unrestricted non-commercial use, distribution, and reproduction in any medium, provided the original work is properly cited.

\begin{abstract}
A 7-year-old patient presented with acute onset spontaneous common peroneal nerve (CPN) palsy due to osteochondroma of fibular head. Osteochondroma was excised resulting in complete neurological recovery. As per our knowledge, this is the first case of an acute onset CPN palsy in a child due to osteochondroma. 14 studies reporting patients with CPN palsy due to osteochondroma were analyzed. Of 24 patients reported with this condition in literature, $19(79 \%)$ recovered completely from CPN palsy. Incomplete recovery after surgery was associated with a longer mean duration between symptoms and surgery (26 months versus 5 months for complete recovery).
\end{abstract}

Keywords: Acute, Common peroneal, Osteochondroma, Nerve palsy, Foot drop, Pediatric

\section{INTRODUCTION}

Osteochondroma, considered as most common bone tumor, represents $8 \%$ of all bone tumors and $34 \%$ of benign cartilaginous tumors. ${ }^{1,2}$ They are frequently asymptomatic and have low malignant potential when sporadic and solitary. It usually arises from the metaphyseal or metadiaphyseal zones of long bones of the appendicular skeleton and are most commonly seen around the knee. ${ }^{3}$ Osteochondromas grow during childhood through adolescence, but usually growth ends when the epiphyseal plate closes. Nerve compressions due to osteochondromas are rare and occur in less than $1 \%$ of all cases. ${ }^{4,5}$ They are more likely to occur with bulky osteochondromas and multiple hereditary osteochondromatosis.

Common peroneal nerve (CPN) is the most commonly involved nerve in compressive neuropathy in the lower extremity and 3rd most common in body after median and ulnar nerve entrapment. ${ }^{6,7}$ The most common location of compression of CPN is neck of fibula followed by popliteal fossa and tibial plateau. In terms of etiology of CPN palsy, the most common is trauma and tumor as a cause is responsible in $6 \%$ of cases. ${ }^{8}$ Acute onset peroneal nerve palsy due to proximal fibular osteochondroma is extremely rare and only one case of this kind has been reported in an adult. To the best of our knowledge, no previous study has reported an acute onset CPN palsy in a child due to osteochondroma.

The purpose of this study was to report the clinical presentation and outcomes after surgical treatment in a child with CPN palsy due to fibular head osteochondroma. A secondary aim was to review the literature for similar studies. 


\section{CASE REPORT}

A 7 year-old girl presented with a left foot drop with a high stepping gait since 8 days. While there was no history of trauma, patient gave a history of sleeping over a hard surface in left lateral position on the night preceding her symptoms. On examination, there was grade 0 power for ankle dorsiflexion. There was no sensory loss.

Plain radiographs showed a sessile bony growth at the proximal fibula (Figure 1A and 1B).

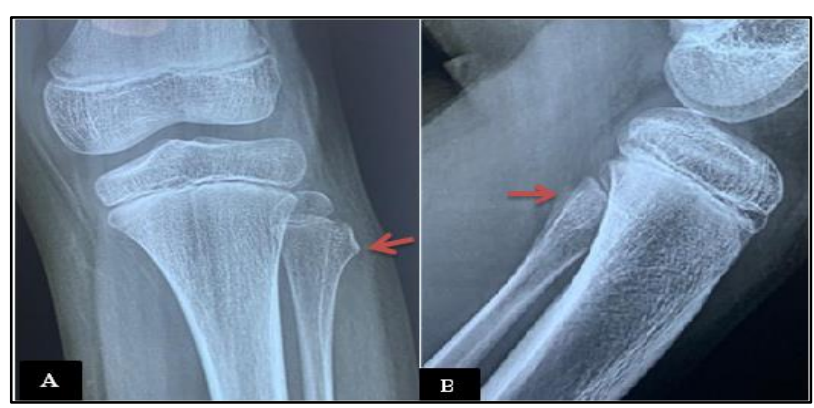

Figure 1: Plain radiograph of knee showing osteochondroma (arrows) in (A) anteroposterior and (B) lateral views.

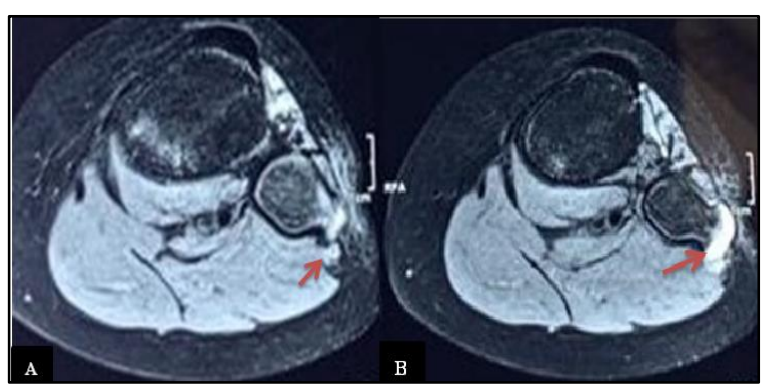

Figure 2: MRI pictures showing osteochondroma (A) tenting of the common peroneal nerve due to tumor (arrow). (B) cartilage cap (arrow).

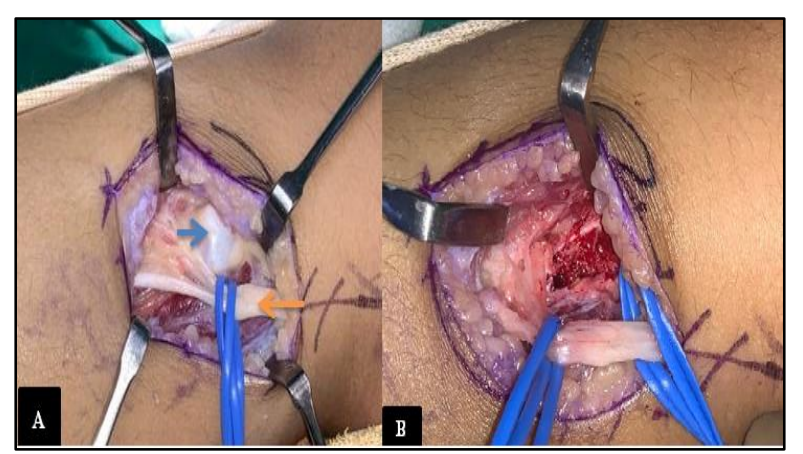

Figure 3: Intraoperative dissection showing (A) osteochondroma (blue arrow) and common peroneal nerve (orange arrow) and (B) decompression of CPN after removal of osteochondroma.

Magnetic resonance imaging (MRI) showed a focal osseous outgrowth at the fibular head neck region laterally which had cortical and medullary integrity with the native bone. The surrounding cartilage gap had a thickness of approximately $3.1 \mathrm{~mm}$. MRI images also showed tenting of peroneal nerve at fibular neck by the lateral edge of the osteochondroma (Figure 2A and 2B).

The electrophysiological study reported that the CPN action potential was absent above the knee. Electromyography (EMG) revealed active and severe denervation in left tibialis anterior. Sensory conduction findings were normal.

The patient was operated 15 days after onset of symptoms. The peroneal nerve was surgically decompressed by excising the osteochondroma. Intraoperatively, the tenting of CPN by lateral edge of osteochondroma was found (Figure $3 \mathrm{~A}$ ). The osteochondroma measuring $2.5 \times 2 \times 1.5$ $\mathrm{cm}$ was excised. The excision surgery was performed by senior author (SK) wherein CPN was further decompressed by perineural neurolysis (Figure 3B).

Postoperatively the patient was given a static ankle foot splint and advised passive range of motion and encouraged for active movements of ankle joint. Patient began regaining ankle dorsiflexion at 4 weeks after surgery. At 3 months, patients regained full power of ankle dorsiflexion. At the final follow up of 1 year, patient was able to perform all daily living and recreational activities.

\section{DISCUSSION}

For literature review on the topic, a search was done in Medline database on June 9, 2021. Our search was conducted using the following search words: "proximal fibular osteochondroma" OR "proximal fibular exostosis" OR "fibular head osteochondroma" OR "osteocartilagenous exostosis of fibula" AND "peroneal nerve palsy" OR "foot drop" OR "drop foot" OR "common peroneal nerve palsy" OR "paresis of peroneal nerve" OR "extension loss of great toe". Inclusion criteria were studies which reported a CPN palsy due to proximal fibular osteochondroma with a diagnosis established through clinical and radiographic findings and reported final status of neurological recovery. Studies were excluded if the studies were unrelated to topic, patients were treated nonoperatively, unavailability of full article text, and incomplete data on clinical presentation and recovery of patients.

The data noted from the previous similar studies were the study design (case report/case series), year of publication, demographics of the patients (age and sex), symptoms and their duration, osteochondroma/s elsewhere in the body, radiographic findings, electrophysiological study findings, intraoperative findings, extent of neural recovery, and duration of final follow up. The demographic variables, symptoms, treatment, and neurological recovery of patients reported in the included studies were presented in a table (Table 1) and as descriptive statistics. 
Keny SM et al. Int J Res Orthop. 2022 Mar;8(2):268-274

Table 1: In line with these findings, previous studies indicate that the surgical decompression of CPN with osteochondroma excision should be performed within 3 months of symptoms to optimize chances of complete neurological recovery. ${ }^{13,14,23-25}$.

\begin{tabular}{|c|c|c|c|c|c|c|c|c|c|c|c|}
\hline Author & $\begin{array}{l}\text { Age } \\
\text { in } \\
\text { year }\end{array}$ & Sex & Symptom & $\begin{array}{l}\text { Duration } \\
\text { of } \\
\text { symptoms } \\
\text { in months }\end{array}$ & $\begin{array}{l}\text { Multiple } \\
\text { lesions } \\
\text { in body }\end{array}$ & radiographic finding & $\begin{array}{l}\text { Preoperative } \\
\text { EMG/NCS }\end{array}$ & $\begin{array}{l}\text { Size } \\
(\mathbf{c m})\end{array}$ & Operative findings & $\begin{array}{l}\text { Nerve } \\
\text { recovery }\end{array}$ & $\begin{array}{l}\text { Final } \\
\text { Follow } \\
\text { up }\end{array}$ \\
\hline $\begin{array}{l}\text { Cherrad et } \\
\text { al }^{9}\end{array}$ & 14 & M & $\begin{array}{l}\text { Difficulty } \\
\text { walking, gradual } \\
\text { weakness of } \\
\text { foot } \\
\text { dorsiflexion, } \\
\text { tingling and } \\
\text { numbness over } \\
\text { the back of left } \\
\text { foot. }\end{array}$ & 3 & No & $\begin{array}{l}\text { Osteophytic } \\
\text { protuberance from } \\
\text { neck of fibula }\end{array}$ & $\begin{array}{l}\text { Prolonged distal } \\
\text { latency and severely } \\
\text { decreased CMAP } \\
(>50 \%)\end{array}$ & NS & $\begin{array}{l}\text { exostosis of the } \\
\text { fibular head, } \\
\text { compressing } \\
\text { and displacing the } \\
\text { CPN }\end{array}$ & Complete & 3 months \\
\hline \multirow{6}{*}{ 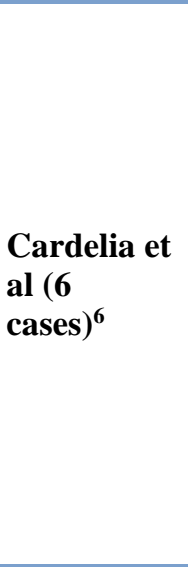 } & 10 & M & $\begin{array}{l}\text { Pain } \\
\text { Weak toe } \\
\text { extension }\end{array}$ & 18 & No & $\begin{array}{l}\text { Sessile lesion at } \\
\text { fibular head }\end{array}$ & $\begin{array}{l}\text { Peroneal conduction } \\
\text { delay }\end{array}$ & $2 \times 3 \times 2$ & $\begin{array}{l}\text { Lesion distal to } \\
\text { nerve }\end{array}$ & Complete & 6 weeks \\
\hline & 8 & M & Pain & 7 & Yes & $\begin{array}{l}\text { Tibiofibular diastasis, } \\
\text { sessile lesion }\end{array}$ & Peroneal palsy & $2 \times 2 \times 3$ & $\begin{array}{l}\text { Nerve running } \\
\text { through groove in } \\
\text { lesion }\end{array}$ & Complete & NS \\
\hline & 7 & M & Pain, paresthesia & 8 & Yes & $\begin{array}{l}\text { Tibiofibular diastasis, } \\
\text { shortened fibula }\end{array}$ & $\begin{array}{l}\text { Anterior tibial nerve } \\
\text { denervation }\end{array}$ & $5 \times 4 \times 3$ & $\begin{array}{l}\text { Enbloc fibular head } \\
\text { excision }\end{array}$ & Complete & NS \\
\hline & 13 & $\mathrm{~F}$ & $\begin{array}{l}\text { Weak foot and } \\
\text { toe dorsiflexion, } \\
\text { parasthesia }\end{array}$ & 24 & No & $\begin{array}{l}\text { Pedunculated lesion } \\
\text { at fibular head }\end{array}$ & $\begin{array}{l}\text { Conduction delay of } \\
\text { peroneal nerve at } \\
\text { fibular head }\end{array}$ & NS & $\begin{array}{l}\text { Fibrous tunnel and } \\
\text { nerve tenting }\end{array}$ & $\begin{array}{l}\text { Incomple } \\
\text { te }\end{array}$ & 5 years \\
\hline & 14 & $\mathrm{~F}$ & $\begin{array}{l}\text { Weakness after } \\
\text { ambulation }\end{array}$ & 0.5 & No & Sessile lesion & $\begin{array}{l}\text { Abnormal peroneal } \\
\text { transmission }\end{array}$ & $5 \times 3 \times 2$ & $\begin{array}{l}\text { Nerve entrapement } \\
\text { by muscle }\end{array}$ & Complete & NS \\
\hline & 7 & $\mathrm{M}$ & Weakness & 1.5 & No & Sessile lesion & Peroneal neuropathy & $2 \times 1 \times 1$ & Attenuated nerve & Complete & NS \\
\hline Mnif et al ${ }^{10}$ & 11 & M & Foot drop & 3 & Yes & $\begin{array}{l}\text { Osteochondroma of } \\
\text { the fibular head }\end{array}$ & $\begin{array}{l}\text { Denervation } \\
\text { Of the muscles } \\
\text { supplied by the right } \\
\text { Peroneal nerve }\end{array}$ & NS & $\begin{array}{l}\text { Osteochondroma } \\
\text { compressing the } \\
\text { peroneal nerve }\end{array}$ & Complete & 3 years \\
\hline Yoo et al $^{11}$ & 10 & $\mathrm{~F}$ & $\begin{array}{l}\text { Extension } \\
\text { Loss of the right } \\
\text { great toe }\end{array}$ & 2 & No & $\begin{array}{l}\text { Sessile exophytic } \\
\text { Bony growth at the } \\
\text { proximal fibula }\end{array}$ & $\begin{array}{l}\text { Abnormal } \\
\text { spontaneous potential } \\
\text { with a polyphasic } \\
\text { pattern observed in } \\
\text { tib ant \& per. Longus }\end{array}$ & $\begin{array}{l}1.3 \times 1 \\
8 \times 1\end{array}$ & $\begin{array}{l}\text { Exophytic } \\
\text { overgrowth } \\
\text { displaced and } \\
\text { stretched the } \\
\text { peroneal nerve }\end{array}$ & Complete & 3 months \\
\hline 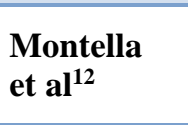 & 19 & M & $\begin{array}{l}\text { Recurrent ankle } \\
\text { sprains }\end{array}$ & 11 & No & $\begin{array}{l}\text { Osteochondroma } \\
\text { arising from the } \\
\text { posterior }\end{array}$ & NS & NS & $\begin{array}{l}\text { Peroneal nerve } \\
\text { stretched over the } \\
\text { top of lesion }\end{array}$ & Complete & 6 months \\
\hline
\end{tabular}




\begin{tabular}{|c|c|c|c|c|c|c|c|c|c|c|c|}
\hline Author & $\begin{array}{l}\text { Age } \\
\text { in } \\
\text { year }\end{array}$ & Sex & Symptom & $\begin{array}{l}\text { Duration } \\
\text { of } \\
\text { symptoms } \\
\text { in months }\end{array}$ & $\begin{array}{l}\text { Multiple } \\
\text { lesions } \\
\text { in body }\end{array}$ & radiographic finding & $\begin{array}{l}\text { Preoperative } \\
\text { EMG/NCS }\end{array}$ & $\begin{array}{l}\text { Size } \\
(\mathrm{cm})\end{array}$ & Operative findings & $\begin{array}{l}\text { Nerve } \\
\text { recovery }\end{array}$ & $\begin{array}{l}\text { Final } \\
\text { Follow } \\
\text { up }\end{array}$ \\
\hline & & & & & & $\begin{array}{l}\text { Surface of right } \\
\text { fibular metaphysis }\end{array}$ & & & & & \\
\hline \multirow{5}{*}{$\begin{array}{l}\text { Cinar et al } \\
(5 \text { cases })^{13}\end{array}$} & 2.5 & M & $\begin{array}{l}\text { Limp after } \\
\text { walking }\end{array}$ & 12 & No & $\begin{array}{l}\text { Posterolateral } \\
\text { exostosis on the } \\
\text { fibular neck }\end{array}$ & $\begin{array}{l}\text { Denervation } \\
\text { of peroneal } \\
\text { muscles }\end{array}$ & NS & $\begin{array}{l}\text { Hourglass sign of } \\
\text { the peroneal truncus }\end{array}$ & Complete & $\begin{array}{l}14 \\
\text { months }\end{array}$ \\
\hline & 15 & M & $\begin{array}{l}\text { Inability to } \\
\text { dorsiflex right } \\
\text { toe }\end{array}$ & 5 & No & $\begin{array}{l}\text { Osteochondroma of } \\
\text { the proximal fibula }\end{array}$ & $\begin{array}{l}\text { Denervation of the } \\
\text { extensor hallucis } \\
\text { longus }\end{array}$ & NS & $\begin{array}{l}\text { Hourglass sign of } \\
\text { the peroneal truncus }\end{array}$ & Complete & $\begin{array}{l}24 \\
\text { months }\end{array}$ \\
\hline & 11 & $\mathrm{~F}$ & $\begin{array}{l}\text { Weak foot } \\
\text { dorsiflexion }\end{array}$ & 4 & No & $\begin{array}{l}\text { Osteochondroma of } \\
\text { the proximal fibula }\end{array}$ & $\begin{array}{l}\text { degeneration of the } \\
\text { peroneal nerve }\end{array}$ & NS & $\begin{array}{l}\text { Hourglass sign of } \\
\text { the peroneal truncus }\end{array}$ & Complete & $\begin{array}{l}50 \\
\text { months }\end{array}$ \\
\hline & 14 & M & $\begin{array}{l}\text { Weak foot } \\
\text { dorsiflexion }\end{array}$ & 5 & No & $\begin{array}{l}\text { Osteochondroma } \\
\text { from proximal fibula }\end{array}$ & $\begin{array}{l}\text { degeneration of the } \\
\text { peroneal nerve }\end{array}$ & NS & $\begin{array}{l}\text { Bursitis due to } \\
\text { Osteochondroma } \\
\text { around the } \\
\text { peroneal trunk }\end{array}$ & Complete & $\begin{array}{l}36 \\
\text { months }\end{array}$ \\
\hline & 10 & $\mathrm{~F}$ & Foot drop & 3 & No & $\begin{array}{l}\text { Osteochondroma } \\
\text { from proximal fibula }\end{array}$ & $\begin{array}{l}\text { degeneration of the } \\
\text { peroneal nerve }\end{array}$ & NS & $\begin{array}{l}\text { Bursitis due to } \\
\text { Osteochondroma } \\
\text { around the } \\
\text { peroneal trunk }\end{array}$ & Complete & $\begin{array}{l}40 \\
\text { months }\end{array}$ \\
\hline $\begin{array}{l}\text { Flores et } \\
\text { al }^{14}\end{array}$ & 15 & M & $\begin{array}{l}\text { Right foot and } \\
\text { toe extension } \\
\text { weakness }\end{array}$ & 4 & No & $\begin{array}{l}\text { Tumor arising from } \\
\text { proximal fibula }\end{array}$ & $\begin{array}{l}\text { denervation of the } \\
\text { muscles supplied by } \\
\text { the right peroneal } \\
\text { nerve }\end{array}$ & NS & $\begin{array}{l}\text { exostosis of the } \\
\text { fibular head } \\
\text { compressing and } \\
\text { displacing the } \\
\text { common peroneal } \\
\text { nerve }\end{array}$ & Complete & 1 months \\
\hline $\begin{array}{l}\text { Demiroglu } \\
\text { et } \text { al }^{15}\end{array}$ & 13 & M & Foot drop & 6 & Yes & $\begin{array}{l}\text { Multiple bony } \\
\text { exostosis arising from } \\
\text { proximal tibia and } \\
\text { fibula, distal femur, } \\
\text { proximal humerus, } \\
\text { and the left forearm. }\end{array}$ & $\begin{array}{l}\text { Denervation of the } \\
\text { nerve muscle } \\
\text { supplied by the deep } \\
\text { peroneal }\end{array}$ & NS & $\begin{array}{l}\text { Peroneal nerve } \\
\text { looks edematous } \\
\text { and inflamed with } \\
\text { tibial } \\
\text { osteochondroma at } \\
\text { the level of fibular } \\
\text { neck. }\end{array}$ & $\begin{array}{l}\text { Incomple } \\
\text { te }\end{array}$ & 6 weeks \\
\hline $\begin{array}{l}\text { Gokkus et } \\
\text { al }^{16}\end{array}$ & 6 & M & $\begin{array}{l}\text { Pain over the } \\
\text { anterolateral } \\
\text { aspect of the } \\
\text { right proximal } \\
\text { leg. }\end{array}$ & NS & No & $\begin{array}{l}\text { Cauliflower-like } \\
\text { growth arising from } \\
\text { proximal } \\
\text { Fibula }\end{array}$ & NS & $5 \times 3 \times 3$ & $\begin{array}{l}\text { Peroneal nerve } \\
\text { adjacent to the } \\
\text { lesion }\end{array}$ & Complete & NS \\
\hline Kim et al $^{17}$ & 20 & $\mathrm{~F}$ & $\begin{array}{l}\text { Extension } \\
\text { weakness of }\end{array}$ & 9 & No & Stalked & $\begin{array}{l}\text { decrease in the SNAP } \\
\text { of the sacral peroneal } \\
\text { nerve and a moderate }\end{array}$ & $\begin{array}{l}2 \times \\
2.1 \times \\
1.2\end{array}$ & $\begin{array}{l}\text { Common peroneal } \\
\text { nerve compressed } \\
\text { by tumor }\end{array}$ & Complete & 1 year \\
\hline
\end{tabular}




\begin{tabular}{|c|c|c|c|c|c|c|c|c|c|c|c|}
\hline Author & $\begin{array}{l}\text { Age } \\
\text { in } \\
\text { year }\end{array}$ & Sex & Symptom & $\begin{array}{l}\text { Duration } \\
\text { of } \\
\text { symptoms } \\
\text { in months }\end{array}$ & $\begin{array}{l}\text { Multiple } \\
\text { lesions } \\
\text { in body }\end{array}$ & radiographic finding & $\begin{array}{l}\text { Preoperative } \\
\text { EMG/NCS }\end{array}$ & $\begin{array}{l}\text { Size } \\
(\mathrm{cm})\end{array}$ & Operative findings & $\begin{array}{l}\text { Nerve } \\
\text { recovery }\end{array}$ & $\begin{array}{l}\text { Final } \\
\text { Follow } \\
\text { up }\end{array}$ \\
\hline & & & $\begin{array}{l}\text { foot and great } \\
\text { toe }\end{array}$ & & & $\begin{array}{l}\text { Osteochondral tumor } \\
\text { protruding outward } \\
\text { on the fibula head }\end{array}$ & $\begin{array}{l}\text { decrease in the } \\
\text { CMAP of deep } \\
\text { peroneal nerve }\end{array}$ & & & & \\
\hline $\begin{array}{l}\text { Manohara } \\
\text { n et al }{ }^{18}\end{array}$ & 21 & $\mathrm{~F}$ & $\begin{array}{l}\text { Foot drop, } \\
\text { burning } \\
\text { sensation in leg }\end{array}$ & $\begin{array}{l}\text { Immediate } \\
\text { post } \\
\text { caesarean } \\
\text { section } \\
\text { (spinal } \\
\text { anesthesia } \\
\text { was given } \\
\text { in lateral } \\
\text { position) }\end{array}$ & Yes & $\begin{array}{l}\text { Multiple exostosis } \\
\text { over the } \\
\text { Medial aspect of the } \\
\text { proximal tibia, over } \\
\text { the medial and } \\
\text { posterior } \\
\text { Aspect of the } \\
\text { proximal fibula }\end{array}$ & $\begin{array}{l}\text { nonstimulatible right } \\
\text { common peroneal } \\
\text { nerve }\end{array}$ & NS & $\begin{array}{l}\text { osteochondroma } \\
\text { was found } \\
\text { displacing the } \\
\text { CPN }\end{array}$ & Complete & 6 months \\
\hline $\begin{array}{l}\text { Paprottka } \\
\text { et al }{ }^{19}\end{array}$ & 19 & $\mathrm{~F}$ & $\begin{array}{l}\text { Weakness of toe } \\
\text { dorsiflexion, } \\
\text { Pain and loss of } \\
\text { sensitivity in } \\
\text { first web space }\end{array}$ & 6 years & No & $\begin{array}{l}\text { 4-cm long brace-like } \\
\text { Exostosis } 6 \mathrm{~cm} \\
\text { underneath her left } \\
\text { fibular head }\end{array}$ & $\begin{array}{l}\text { NCV :not detectable, } \\
\text { distal motor } \\
\text { latency:delayed, } \\
\text { distal amplitude: } \\
\text { reduced }\end{array}$ & $4 \times 1$ & $\begin{array}{l}\text { chronic pressure } \\
\text { damage to the deep } \\
\text { peroneal nerve with } \\
\text { prestenotic swelling }\end{array}$ & $\begin{array}{l}\text { Incomple } \\
\text { te }\end{array}$ & 1 week \\
\hline $\begin{array}{l}\text { Watson et } \\
\text { al }^{20}\end{array}$ & 12 & M & $\begin{array}{l}\text { Weakness of toe } \\
\text { and foot } \\
\text { extension } \\
\text { Tingling and } \\
\text { numbness over } \\
\text { first web space }\end{array}$ & 3 months & No & $\begin{array}{l}\text { Ostochondroma of } \\
\text { proximal fibular } \\
\text { metaphysis }\end{array}$ & $\begin{array}{l}\text { Motor units } \\
\text { unavailable for } \\
\text { tibialis anterior } \\
4+\text { insertional } \\
\text { activity, } 2+ \\
\text { fibrillation potential }\end{array}$ & $\begin{array}{l}2.5 \times 1 \text {. } \\
5\end{array}$ & $\begin{array}{l}\text { Hourglass } \\
\text { configuration of the } \\
\text { nerve caused by } \\
\text { fascial bands from } \\
\text { the origin of } \\
\text { peroneal muscles } \\
\text { compressing nerve } \\
\text { againt the mass }\end{array}$ & $\begin{array}{l}\text { Incomple } \\
\text { te }\end{array}$ & 4 months \\
\hline $\begin{array}{l}\text { Oxner et } \\
\text { al }^{21}\end{array}$ & 8 & $\mathrm{~F}$ & Foot drop & 3 months & No & $\begin{array}{l}\text { Bony growth from } \\
\text { proximal } \\
\text { fibula }\end{array}$ & $\begin{array}{l}\text { Peroneal nerve palsy } \\
\text { With conduction } \\
\text { block in the region of } \\
\text { the right fibular head }\end{array}$ & NS & $\begin{array}{l}\text { Peroneal nerve } \\
\text { Noted to be thinned } \\
\text { and } \\
\text { stretched over the } \\
\text { lesion }\end{array}$ & Complete & NS \\
\hline $\begin{array}{l}\text { Current } \\
\text { study }\end{array}$ & 7 & $\mathrm{~F}$ & Foot drop & 8 days & No & $\begin{array}{l}\text { Sessile } \\
\text { Osteochondroma } \\
\text { from proximal fibula }\end{array}$ & $\begin{array}{l}\text { Active and severe } \\
\text { denervation in tibialis } \\
\text { anterior muscle, left } \\
\text { CPN CMAP } \\
\text { attenuated distally } \\
\text { and above the knee }\end{array}$ & $\begin{array}{l}2.5 \times 2 \\
\times 1.5\end{array}$ & $\begin{array}{l}\text { Osteochondroma } \\
\text { tenting the common } \\
\text { peroneal nerve }\end{array}$ & Complete & $\begin{array}{l}12 \\
\text { months }\end{array}$ \\
\hline
\end{tabular}


The age of COHORT of patients from previous and current study were presented as mean and standard deviation. Initial search yielded a total of 2006 articles. The title and abstract of these articles were screened independently by two authors for their relevance to subject. 1990 articles were not related to the topic of interest.

Full text of 16 studies were assessed based on exclusion criteria. Out of 16 studies, two were excluded; one due to unavailability of full text and another due to lack of information regarding age, sex, chronicity of symptoms, intraoperative findings and duration of final follow up. Finally, 14 studies were included in the analysis. Of the 14 included studies, 12 were case reports and 2 were case series (Table 1). ${ }^{6,9-21}$ A total of 24 patients (including one from this study) were included in the analysis. Mean age and standard deviation of patients were 12 years and 4.7, respectively. There were 14 male $(58 \%)$ and 10 female $(62 \%)$ patients. There were 20 children and 4 adults. One adult patient (previous study) and one child (current study) had acute, and rest 22 patients had gradual onset of symptoms. 16 patients complained of only motor symptoms, 3 patients complained of only sensory symptoms, and 5 patients had both. Upon radiography, all the patients had bony overgrowth from proximal fibula either as a sessile or pedunculated lesion. 5 out of 24 (21\%) patients had multiple osteochondromatosis.

All the patients underwent surgical removal of osteochondroma. Out of 24 patients (including the one patient of this study), 20 patients $(83 \%)$ had complete neurological recovery. Incomplete recovery of nerve function after surgery was associated with the duration of symptoms as mean of onset of duration of symptoms was 5 months in patients who had complete recovery as compared to 26 months in patients who had incomplete recovery. This is the first report in literature of a child with acute onset CPN palsy due to osteochondroma. Based on literature review, complete neurological recovery rate after surgical decompression is $83 \%$. This report also highlights the importance of early surgical intervention to decompress the CPN in the setting of compressive neuropathy due to osteochondroma.

An acute onset of CPN palsy without trauma and due to osteochondroma as reported here is an unusual presentation. The reason of acute onset CPN palsy in the child we reported is unclear. We speculate that the possible reason of acute onset of symptoms could be due to patient's dependent position of the leg while sleeping causing CPN compression similar to saturday night palsy. ${ }^{22}$ The authors of previous study who reported similar case of acute onset CPN palsy, but in an adult, stated that the palsy developed after the patient was given spinal anaesthesia in dependent lateral position. The size of the osteochondroma in this report was of one of the smallest dimensions among the searched literature $(2.5 \times 2 \times 1.5 \mathrm{~cm})$. A relatively smaller sized lesion causing compressive neuropathy of CPN could be explained by the fact that the patient in this report was a child with seemingly less space for the lesion to grow before it starts compressing the $\mathrm{CPN}$.

One of the reasons for complete recovery of CPN after compressive neuropathy in this case was early intervention after presentation. Our analysis of 24 patients included from this and previous studies showed that the patients who recovered completely after surgery had surgery at a mean of 5 months from symptoms compared to those with incomplete recovery who were operated at a mean of 26 months after onset of symptoms. In line with these findings, previous studies indicate that the surgical decompression of CPN with osteochondroma excision should be performed within 3 months of symptoms to optimize chances of complete neurological recovery. ${ }^{13,14,23-25}$ This study has several limitations. First, similar to most of the previous relevant studies, the design here is a case report. This limits the ability of our review to suggest conclusive evidence to diagnose and treat this rare condition.

\section{CONCLUSION}

We report the first case in literature of acute onset CPN palsy in a child due to osteochondroma who recovered completely after surgical decompression of the nerve. Our own experience and that from the limited available literature suggests that an early surgical decompression of CPN with osteochondroma excision at least 5 months from onset of symptoms is key for complete neurological recovery.

\section{Funding: No funding sources Conflict of interest: None declared Ethical approval: Not required}

\section{REFERENCES}

1. Tong K, Liu H, Wang X. Osteochondroma: Review of 431 patients from one medical institution in South China. J Bone Oncol. 2017;8:23-29.

2. Bovée JV. Multiple osteochondromas. Orphanet J Rare Dis. 2008;3:3.

3. Dorfman HD, Mosby CB. St. Louis: 1998. Osteochondroma. Bone tumors. 1998;331-46.

4. Göçmen S, Topuz AK, Atabey C, Şimşek H, Keklikçi $\mathrm{K}$, Rodop O. Peripheral nerve injuries due to osteochondromas: analysis of 20 cases and review of the literature. J Neurosurg. 2014;120(5):1105-12.

5. N.-J. Paik, T. R. Han, and S. J. Lim, "Multiple peripheral nerve compressions related to malignantly transformed hereditary multiple exostoses," Muscle \& Nerve. 2000;23(8):1290-4.

6. Cardelia JM, Dormans JP, Drummond DS, Davidson RS, Duhaime C, Sutton L. Proximal fibular osteochondroma with associated peroneal nerve palsy: a review of six cases. J Pediatr Orthop. 1995;15(5):574-7. 
7. D. M. Dawson, M. Hallett, L. Millender, Entrapment Neuropathies, Little, Brown and Company, Boston, MA, USA, 2nd edition. 1990.

8. Arabi H, Bakzaza O, El Fikri A, Elktaibi A, Saidi H, El Alaoui M. Compression of the peroneal nerve by a neurofibroma originating from collaterals of the peroneal nerve: a case report. J Med Case Rep. 2016;10:28.

9. Cherrad T, Bennani M, Zejjari H, Louaste J, Amhajji L. Peroneal Nerve Palsy due to Bulky Osteochondroma from the Fibular Head: A Rare Case and Literature Review. Case Reports in Orthopedics. 2020;8825708.

10. Mnif H, Koubaa M, Zrig M, Zammel N, Abid A. Peroneal nerve palsy resulting from fibular head osteochondroma. Orthopedics. 2009;32(7):528.

11. Yoo JH, Min KD, Kim CK. A case of extension loss of great toe due to peroneal nerve compression by an osteochondroma of the proximal fibula. Arch Orthop Trauma Surg. 2010;130:1071-5.

12. Montella BJ, O'Farrell DA, Furr WS, Harrelson JM. Fibular osteochondroma presenting as chronic ankle sprain. Foot Ankle Int. 1995;16(4):207-9.

13. Çınar A, Yumrukçal F, Salduz A, Dirik Y, Eralp L. A rare cause of 'drop foot' in the pediatric age group: Proximal fibular osteochondroma a report of 5 cases. Int J Surg Case Rep. 2014;5(12):1068-71.

14. Flores LP, Koerbel A, Tatagiba M. Peroneal nerve compression resulting from fibular head osteophytelike lesions. Surg Neurol. 2005;64(3):249-52.

15. Demiroğlu M, Özkan K, Kılıç B, Akçal A, Akkaya M, Özkan FÜ. Deep peroneal nerve palsy due to osteochondroma arising from fibular head and proximal lateral tibia. Int J Surg Case Rep. 2017;31:200-2.

16. Gökkuş K, Atmaca H, Sağtaş E, Saylik M, Aydin AT. Osteochondromas originating from unusual locations complicating orthopedic discipline: case series. Eklem Hastalik Cerrahisi. 2015;26(2):100-9.
17. Kim YJ, Lee JW, Chea SU, Yang JH. Case Report : A Case of Peroneal Nerve Palsy Secondary to Fibular Head Osteochondroma. Knee Surg Relat Res. 2011;23(1):47-50

18. Manoharan A, Suresh SS, Sankaranarayanan L. Proximal Fibular Osteochondroma Producing Common Peroneal Nerve Palsy in a Post-Cesarean Section Patient. Oman Med J. 2013;28(3):e047.

19. Paprottka FJ, Machens HG, Lohmeyer JA. Partially irreversible paresis of the deep peroneal nerve caused by osteocartilaginous exostosis of the fibula without affecting the tibialis anterior muscle. J Plast Reconstr Aesthet Surg. 2012;65(8):e223-5.

20. Watson LW, Torch MA. Peroneal nerve palsy secondary to compression from an osteochondroma. Orthopedics. 1993;16(6):707-10.

21. Gallagher-Oxner K, Bagley L, Dalinka MK, Kneeland JB. Case report 822: Osteochondroma causing peroneal palsy-imaging evaluation. Skeletal Radiol. 1994;23(1):71-2.

22. Manigoda M, Dujmović-Basuroski I, Trikić R, Drulović J. Acute sciatic neuropathy--"post-Saturday palsy. Srp Arh Celok Lek. 2005;133(1-2):58-61.

23. Marciniak C. Fibular (peroneal) neuropathy: electrodiagnostic features and clinical correlates. Phys Med Rehabil Clin N Am. 2013;24(1):121-37.

24. Lange RH, Lange TA, Rao BK. Correlative radiographic, scintigraphic, and histological evaluation of exostoses. J Bone Joint Surg Am. 1984;66(9):1454-9.

25. Ozden R, Uruc V, Kalacı A, Dogramac1 Y. Compression of common peroneal nerve caused by an extraneural ganglion cyst mimicking intermittent claudication. J Brachial Plex Peripher Nerve Inj. 2013;8(1):5.

Cite this article as: Keny SM, Dabral L, Meshram P, Ansari N, Gokhale N, Nawale S et al. Acute onset common peroneal nerve palsy in a child due to fibular head osteochondroma: a case report. Int J Res Orthop 2022;8:268-74. 